\title{
Predation by fish on intertidal oysters
}

\author{
M. J. Anderson*, S. D. Connell \\ Centre for Research on Ecological Impacts of Coastal Cities, Marine Ecology Laboratories, A11, University of Sydney, \\ New South Wales 2006, Australia
}

\begin{abstract}
Experiments in many parts of the world have indicated that sessile intertidal organisms are affected by fish predation. Farming of oysters Saccostrea commercialis (Iredale \& Roughley) and Crassostrea gigas (Thunberg) in New South Wales, Australia, depends on their natural recruitment and growth on intertıdal structures in estuaries. We investigated the effects of predation by fish on numbers of oysters recruiting to experimental panels of 3 different sizes. We tested effects of excluding fish of different sizes using different sizes of mesh $(12.5$ and $50 \mathrm{~mm})$. Numbers of oysters were significantly reduced on panels open to predatory fish. Numbers of oysters per unit area and subsequent predation on them did not vary, however, across 3 different sizes of panels, indicating that predation was not dependent on patch size. Mortality on panels open to predation averaged $40.0 \%( \pm 4.3 \% \mathrm{SE})$. Fish also significantly altered the distribution of sizes of oysters. The effect of predation was almost entirely attributable to toadfish Tetractenos spp. Previous knowledge of the life history of oysters and succession in these intertidal assemblages suggests that effects of predation may not, however, have important long-term consequences on natural populations.
\end{abstract}

KEY WORDS: Oysters Fish-Size-specific predation-Experimental cages-Recruitment Post-settlement mortality

\section{INTRODUCTION}

Predation has long been viewed as an important factor in structuring subtidal and intertidal marine assemblages (e.g. Connell 1961, Dayton 1971, Paine 1974, Menge \& Sutherland 1976, Karlson 1978, Russ 1980, Creese 1982, Harris \& Irons 1982, Jernakoff \& Fairweather 1985, Menge et al. 1986, Dungan 1987, Petraitis 1990). Predation on bivalve mussels has been found to cause significant impacts in certain areas where mussels are considered to be the dominant competitors for space (e.g. Paine 1974, Menge \& Sutherland 1976, Barkai \& Branch 1988). Despite this, other experimental evidence supports alternative explanations concerning factors that affect the abundance or distributions of mussels (e.g. Dayton 1971, Petraitis 1990).

Predation has been suggested to be instrumental in maintaining the lower limit of the intertidal distribution of another bivalve, the American. oyster Crasso-

\footnotetext{
•E-mail:mjanders@bio.usyd.edu.au
}

strea virginica (Roegner \& Mann 1990). In the northwest Atlantic and Gulf of Mexico, many different kinds of predators affect Crassostrea spp., including birds (Tuckwell \& Nol 1997), whelks and tritons (Garton 1986, Littlewood 1989, Brown 1997), turbellarian flatworms (Littlewood \& Marsbe 1990), crabs (Einer \& Hughes 1978, Bisker \& Castagna 1987, Ogle \& Beaugez 1988, Egglestone 1990, Brown \& Haight 1992) and lobsters (Elner \& Lavoie 1983). Predation by fish (the toadfish Opsanus tau and the ray Rhinoptera bomasis) on these oysters has been mentioned as a possibility (McDermott 1964, Krantz \& Chamberlain 1978), but we know of no quantitative experimental evidence to support this

Similarly, observations and anecdotal evidence suggest that fish eat Sydney rock oysters Saccostrea commercialis (Iredale \& Roughley) and Pacific oysters Crassostrea gigas (Thunberg), which are widespread in estuaries of New South Wales, Australia (Korringa 1976. Wisely et al. 1979, Nell 1993). Fish named as possible predators include bream Acanthopagrus australis (Owen), snapper Chrysophrys auratus (Schneider), toadfish Tetractenos spp., leatherjackets Monacanthus 
chinensis (Osbeck), brown stingrays Dasyatis fluviorum Ogilby and porcupine fish Dichotylichthys punctulatus Kaup (Korringa 1976, Wisely et al. 1979, Nell 1993 and pers. comm.).

There has been no experimental examination or estimation of the possible effects of predation in these systems. This is surprising because commercial farming of oysters depends entirely on the natural recruitment and growth of oysters. Oyster farmers construct wooden intertidal structures for purposes of catching larval oysters and growing them to a marketable size, which takes approximately 2 to $3 \mathrm{yr}$. There are nearly 3500 commercial oyster farms in 30 estuaries in New South Wales, covering a total area of close to 4700 hectares (New South Wales Fisheries 1996). Oyster farms thus form an important habitat and a conspicuous proportion of the intertidal landscape. They contribute much of the available area for larval settlement of benthic species in estuaries.

Oysters are known to have important long-term effects on the structure of these estuarine assemblages as competitive dominants, due to their ability to overgrow other species and one another (Anderson \& Underwood 1994, Underwood \& Anderson 1994). Thus, if predators are affecting oysters, this may have important consequences, not just for the oysters, but also for other species occurring on hard substrata in these habitats (Anderson 1999). In addition, it was observed in a previous study on effects of patch size on colonisation that teeth marks, apparently due to fish, occurred at the edges but not centres of wooden settlement surfaces (Anderson 1998). This suggested that predation may vary with size and shape of patches because the perimeter-to-area ratio changes with the size and shape of patches.

From the anecdotal evidence and these observations, we proposed the following models: (1) predation by fish affects recruitment of oysters; and (2) the intensity of predation varies with the size of the substratum.

In most previous studies of predation, cages have been used to exclude fish from the substratum (e.g. Russ 1980, Choat 1982, Keough \& Downes 1982, Kennelly 1991). Yet, in most studies, because fish are very mobile, the identity of particular species responsible for any predatory effects could only be guessed or inferred from observations (but see Ayling 1981). In intertidal areas of outer bays in estuaries of New South Wales, where oyster spat are 'caught' on structures built on commercial oyster leases (Nell 1993), toadfish appear to be especially abundant (authors' pers. obs.). In addition, oyster shells have been found in the gut contents of toadfish (D. J. Booth unpubl. data). One way that toadfish are distinguishable from the other potential predators is that they have relatively small, elongate bodies. This contrasts with the relatively large and deep-bodied shapes of fish such as bream, snapper or leatherjackets. Thus, we also tested the hypothesis that recruitment of oysters is affected primarily by toadfish, using cages with different sizes of mesh to exclude different sizes (and shapes) of fish.

\section{MATERIALS AND METHODS}

The experiment was done in Salamander Bay, Port Stephens estuary, New South Wales, Australia $\left(32^{\circ} 42^{\prime} \mathrm{S}, 152^{\circ} 00^{\prime} \mathrm{E}\right)$. We used existing intertidal structures used for oyster farming at the site for the experiment. Such structures were described in detail in Nell (1993) and Underwood \& Anderson (1994). The base of the structures generally consists of 2 horizontal parallel beams, about $1 \mathrm{~m}$ apart, supported by posts driven into the sand, so that the beams are level with a tidal mark of ca $0.5 \mathrm{~m}$ above Spring Low Water. Recruitment of oysters was measured using panels made of marine plywood ( $9 \mathrm{~mm}$ thick) measuring $5 \mathrm{~cm} \times 5 \mathrm{~cm}, 10 \mathrm{~cm} \times$ $10 \mathrm{~cm}$ or $20 \mathrm{~cm} \times 20 \mathrm{~cm}$. Two panels of a single size were attached with self-tapping stainless steel screws to a wooden tar-covered stick (1.8 m long), as are usually used for oyster farming (Nell 1993). The sticks were attached perpendicularly across the parallel beams, using non-slip plastic ties, with settlement surfaces facing downwards in the water column (Fig. 1).

The experimental design included full cages to exclude fish, partial cages to control for potential cage artifacts and surfaces open to predation (Fig. 1). Although partial cages do not entirely control for all possible artifacts due to cages, the design of partial cages was made in consideration of potential known

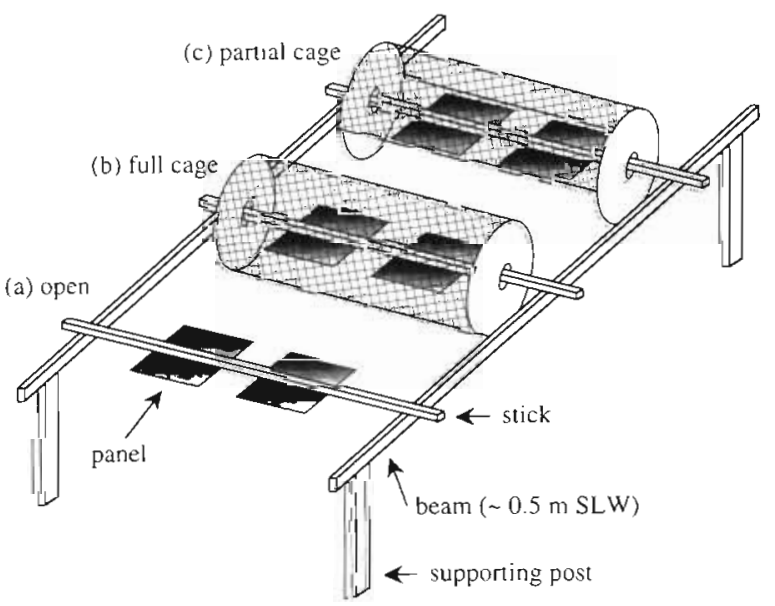

Fig. 1. Schematic diagram of the treatments in the experiment on the structure of an intertidal oyster farm: (a) open panels; (b) panels protected by a full cage and (c) panels open to predation but subject to caging artifacts from a partial cage. SLW: Spring Low Water 
artifacts in these situations, such as changes in light, water flow or sedimentation (e.g. Schmidt \& Warner 1984, Kennelly 1991, Connell 1997, Fig. 1c).

Full cages were constructed as cylinders of zinccoated mesh (900 mm long $\times 300 \mathrm{~mm}$ diameter) around each stick. Round plastic bucket lids at each end provided support for the mesh and attachment to the stick. Cages were constructed with 2 sizes of mesh: a large mesh $(50 \mathrm{~mm})$, which would enable toadfish to enter, but would exclude relatively large and deep-bodied fishes, and a small mesh (12.5 mm) which excluded virtually all predatory fish. These mesh sizes were chosen after preliminary seining at the site and consideration of the distribution of girths of toadfish caught (mean girth $=18.7 \mathrm{~mm}$, range $=11$ to $26 \mathrm{~mm}, \mathrm{n}=20$ ).

Partial cages were constructed as open half-cylinders of mesh, the same dimension and design as the full cages, essentially forming a roof over the panels on an individual stick (Fig. 1c). Partial cages were also constructed using each of the 2 mesh sizes.

For each of the sizes of panels, there were 3 sticks containing $n=2$ panels in each treatment. There were 5 experimental treatments: full cages with either small or large mesh (FS or FL, respectively), open panels (O) and partial cages with either small or large mesh (PS or PL, respectively). Thus, altogether there were 90 panels examined as part of this experiment ( 5 treatments $\times$ 3 sticks $\times 2$ panels $\times 3$ sizes).

The experimental sticks of all treatments were attached to the bases of 2 structures in an oyster farm in Salamander Bay, Port Stephens, on 1 October 1997. Sticks of different treatments were attached to the beams in a haphazard array. Panels were brought back to the lab for analysis on 17 January, 1998 ( $\sim 3$ mo later). Panels were placed under a dissecting microscope and the numbers of oysters and other taxa on each panel were recorded. For panels of sizes $5 \mathrm{~cm} \times 5$ $\mathrm{cm}$ or $10 \mathrm{~cm} \times 10 \mathrm{~cm}$, percentage cover of oysters and other organisms was estimated by counting the number of times each taxon occurred under 25 uniformly placed points in a grid and multiplying by 4 . For panels measuring $20 \mathrm{~cm} \times 20 \mathrm{~cm}$, percentage cover of organisms was estimated by counting the number of times a taxon occurred under 100 uniformly placed points. Results of multivariate analyses concerning the complete assemblage of organisms are presented elsewhere (Connell \& Anderson 1999). Densities of oysters were standardised per $100 \mathrm{~cm}^{2}$.

Pacific oysters Crassostrea gigas commonly settle relatively early in the Australian summer season (November to December), whereas Sydney rock oysters Saccostrea commercialis commonly settle from about January to April (e.g. Anderson 1996). It is virtually impossible to distinguish the 2 species when they are very young (ca $<10 \mathrm{~mm}$ ). In addition to counts, the size of each oyster from the tip of the umbo to its furthest growing edge, was measured with vernier calipers to the nearest $0.1 \mathrm{~mm}$.

A unique aspect of these organisms is that when they die or are removed by predators, the bottom valve of the oyster shell is left on the surface of the panel as a 'scar,' indicating that an oyster was once present. It is therefore possible to count scars as a measure of loss of oysters from panels. We estimated the total number of oysters recruiting over the period of the investigation in each treatment by adding the number of live oysters to the number of scars on each panel. Further, mortality was estimated as a proportion: the number of scars divided by the total number of recruits (= live oysters plus scars). Estimates of sizes of scars were obtained in the same way as for live oysters.

\section{RESULTS}

To test for caging artifacts, we first compared partial cages with small mesh versus partial cages with large mesh versus open panels (factor = Cage, 3 levels, fixed). If there was no statistical evidence of artifacts due to cages, we then tested for effects of predation. Here, we compared full cages with small mesh versus full cages with large mesh versus open panels (factor = Predation, 3 levels, fixed). Each of these analyses was done separately, with Size of panel as a second factor (fixed, with 3 levels).

Preliminary analyses demonstrated that there were no apparent artifacts of cages. There was no difference in the numbers, percentage cover or mortality of oysters on panels protected by a partial cage compared with open panels (Table 1, Fig. 2). Although there was a significant effect of the factor Cage in the preliminary analysis of numbers of oysters per unit area, Student-Newman-Keuls (SNK) tests did not find a consistent pattern of differences among the 3 treatments (Table 1a).

There was no significant difference in total recruitment (number of live oysters plus scars per unit area) among different sizes of panels (factor $=$ Size, $F_{2,18}=$ $0.53, \mathrm{p}>0.59$ ) or among treatments (factor = Predation, $F_{2,18}=2.44, \mathrm{p}>0.10$ ) .

There were significantly greater numbers of oysters on panels inside cages protected by small mesh than on other panels (Table 2a, Fig. 2a). Numbers of oysters did not differ significantly on panels protected by large mesh from those on panels left open to predation (Table 2a, Fig. 2a). These results were consistent for all sizes of panels (non-significant Predator $\times$ Size interaction, Table $2 \mathrm{a}$ ). In addition, numbers of oysters per unit area did not differ significantly on different sizes of panels (Table 2a, Fig. 2a). 
Table 1. Analyses of variance testing for effects of cage artifacts. Analyses compared panels in partial cages made with large mesh versus small mesh versus open panels (factor $=$ Cage, 3 levels, fixed) and size of panel (factor $=$ Size, 3 levels, fixed) for (a) mean number of oysters per $100 \mathrm{~cm}^{2}$, (b) percentage cover of oysters and (c) mortality of oysters, calculated as the number of scars divided by the total number of live oysters plus scars on panels. There were $n=2$ panels on each of 2 sticks in each combination of treatments. Percentage cover data were transformed to $y^{\prime}=\sin ^{-1}(\sqrt{y})$. Variances were homogeneous by Cochran's test for all analyses $(p>0.05)$

\begin{tabular}{|c|c|c|c|c|}
\hline \multirow[t]{2}{*}{ Source } & \multirow[t]{2}{*}{$d f$} & (a) Density & (b) Cover & (c) Mortality \\
\hline & & $F \quad \mathrm{p}$ & $F \quad \mathrm{p}$ & $F \quad \mathrm{p}$ \\
\hline Cage & 2 & $5.04<0.02$ & $0.39>0.68$ & $0.71>0.50$ \\
\hline Size & 2 & $3.20>0.06$ & $0.99>0.39$ & $0.88>0.43$ \\
\hline Cage $\times$ Size & 4 & $0.78>0.55$ & $0.73>0.58$ & $1.33>0.29$ \\
\hline Sticks (Cage $\times$ Size) & 18 & $0.91>0.57$ & $2.33<0.03$ & $0.66>0.82$ \\
\hline Residual & 27 & & & \\
\hline Total & 53 & & & \\
\hline SNK tests & & $\begin{array}{l}\text { small }>\text { open } \\
\text { large }=\text { open } \\
\text { small }=\text { large }\end{array}$ & & \\
\hline
\end{tabular}

however, a decreasing gradient of mortality with decreasing size of panel (Fig. 2c). Significantly greater mortality occurred on open panels than on panels protected by large mesh, which in turn had greater mortality than on panels protected by small mesh (Table 2c, SNK test, Fig. 2c). Thus, although numbers of oysters and total numbers of recruits were not statistically significantly different on panels protected with large mesh compared with open panels (Table 2a, Fig. 2a), there was some additional source of mortality on open panels (Fig. 2c). This was shown by a difference between these 2 treatments in the ratio of live oysters to scars (compare FL with $\mathrm{O}$, Fig. 3). There was virtually no mortality on panels inside cages made of small mesh (Figs. 2c \& 3). Mortality on panels open to predation averaged $40.0 \%$ $( \pm 4.3 \% \mathrm{SE})$.

The mean percentage cover of oysters was also greater on panels protected by small mesh (ca 20\%) than on other panels (ca 5\%, Fig. 2b). Although the predation treatments differed significantly in the analysis of variance, multiple comparisons were not consistent (SNK tests, Table 2b). In treatments protected by cages with large mesh, panels measuring $5 \mathrm{~cm} \times 5 \mathrm{~cm}$ had apparently greater percentage cover of oysters than did larger sized panels (Fig. 2b), but there was no significant interaction of treatments with size of panel (Table $2 \mathrm{~b}$ ).

In addition, mortality of oysters did not differ from one size of panel to another (Table 2c). There was,
Distributions of size frequencies of live oysters in different predation treatments were plotted and analysed using multiple Komolgorov-Smirnov 2-sample tests (Sokal \& Rohlf 1981). Sizes of scars ranged from 1 to $30 \mathrm{~mm}$, but live oysters ranged from 1 to $54 \mathrm{~mm}$ (Fig. 4). The smallest panels did not have enough oysters to estimate distributions of sizes. Panels protected by cages with small mesh had long broad right-hand tails to their distributions, consisting of larger oysters (ca $>8 \mathrm{~mm}$ shell length, Fig. $4 \mathrm{a}, \mathrm{b}$ ). In contrast, virtually all of the oysters on panels protected by large mesh cages or left open were quite small (ca $<8 \mathrm{~mm}$, Fig. $4 \mathrm{c}$ to $\mathrm{f}$ ).

Table 2. Analyses of variance testing for effects of predation. Analyses compared panels in full cages made with large mesh versus small mesh versus open panels (factor = Predation, 3 levels, fixed) and size of panel (factor $=$ Size, 3 levels, fixed) for (a) mean number of oysters per $100 \mathrm{~cm}^{2}$, (b) percentage cover of oysters and (c) mortality of oysters, calculated as the number of scars divided by the total number of live oysters plus scars on panels. There were $n=2$ panels on each of 2 sticks in each combination of treatments. Percentage cover data were transformed to $y^{\prime}=\sin ^{-1}(\sqrt{y})$, but variances were still heterogeneous (Cochran's test, $\mathrm{p}<0.05)$. Variances were homogeneous for the other 2 variables by Cochran's test $(p>0.05)$

\begin{tabular}{|c|c|c|c|c|c|c|c|}
\hline \multirow[t]{2}{*}{ Source } & \multirow[t]{2}{*}{$d f$} & \multicolumn{2}{|c|}{ (a) Density } & \multicolumn{2}{|c|}{ (b) Cover } & \multicolumn{2}{|c|}{ (c) Mortality } \\
\hline & & $F$ & $\mathrm{p}$ & $F$ & $\mathrm{p}$ & $F$ & $\mathrm{p}$ \\
\hline Predation & 2 & 23.45 & $<0.001$ & 6.23 & $<0.01$ & 30.16 & $<0.001$ \\
\hline Size & 2 & 0.78 & $>0.47$ & 1.00 & $>0.38$ & 0.41 & $>0.66$ \\
\hline Predation $\times$ Size & 4 & 1.31 & $>0.30$ & 0.93 & $>0.46$ & 1.32 & $>0.30$ \\
\hline Sticks (Predation $\times$ Size) & 18 & 1.10 & $>0.40$ & 2.02 & $<0.05$ & 1.21 & $>0.32$ \\
\hline Residual & 27 & & & & & & \\
\hline Total & 53 & & & & & & \\
\hline SNK tests & & small $\gg$ & $e=$ open & & $\begin{array}{l}\text { pen } \\
\text { pen } \\
\text { arge }\end{array}$ & open $\geqslant$ & $e \gg$ small \\
\hline
\end{tabular}



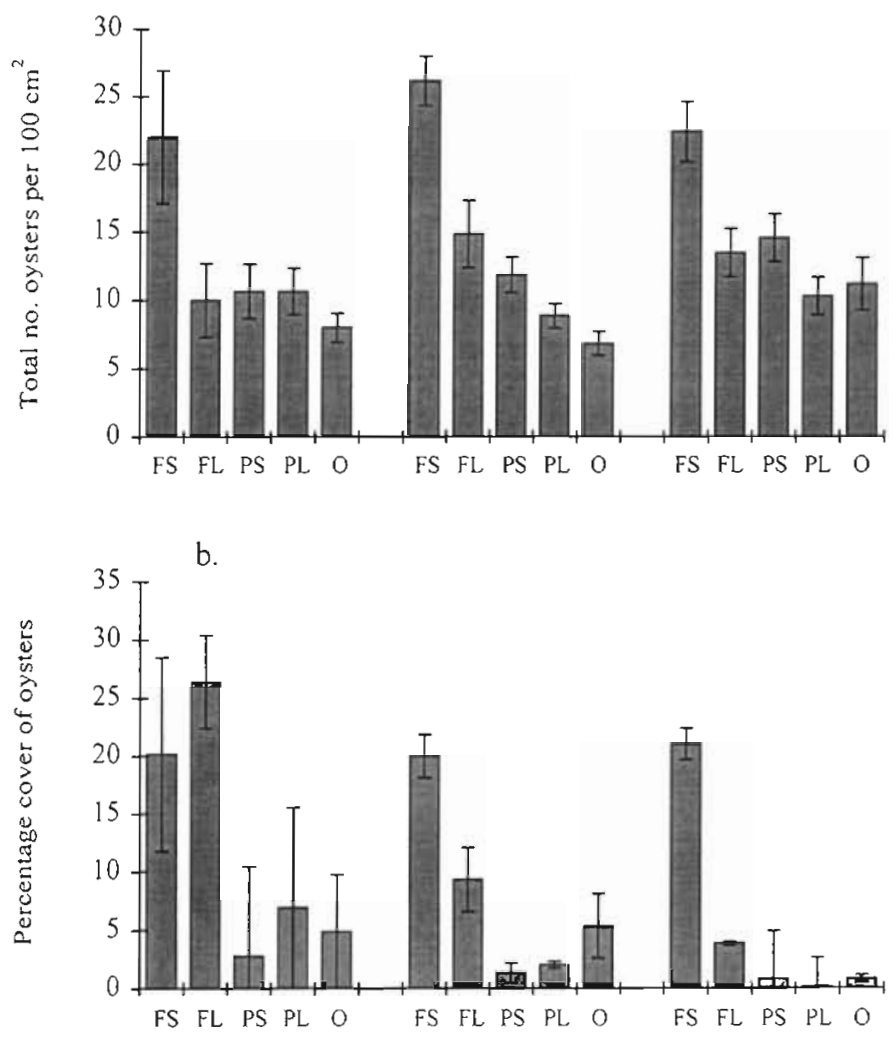

c.

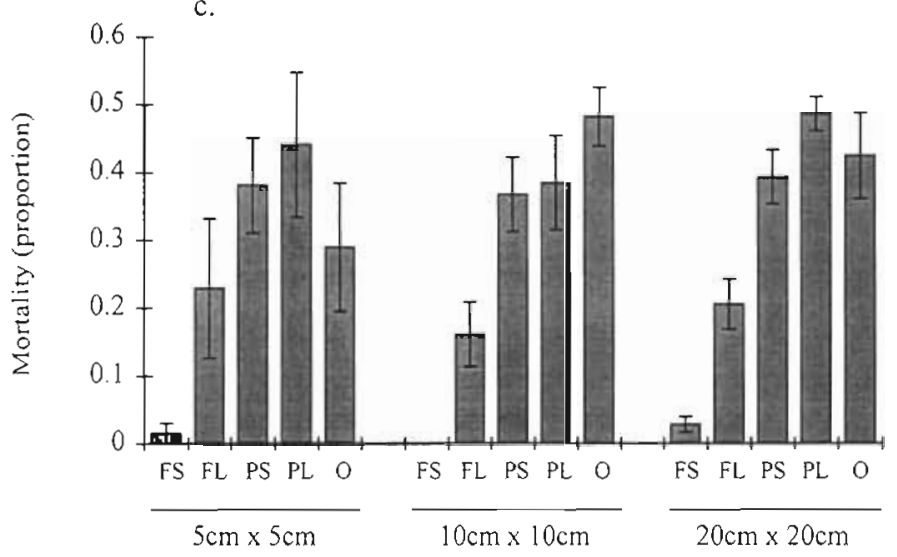

Fig. 2. Mean ( $\pm 1 \mathrm{SE}$ ) (a) number of live oysters, (b) percentage cover of oysters and (c) mortality of oysters in each of the treatments of the experiment: $F=$ full cages, $P=$ partial cages, $\mathrm{L}=$ large mesh, $\mathrm{S}=$ small mesh, $\mathrm{O}=$ open panels; $\mathrm{n}=6$ (2 panels on each of 3 sticks)

Sizes of oysters on $20 \mathrm{~cm} \times 20 \mathrm{~cm}$ panels in cages with small mesh differed significantly from those on panels in cages with large mesh and from those on open panels; the latter 2, however, did not differ (Komolgorov-Smirnov tests, Table 3). A similar result was obtained for panels measuring $10 \mathrm{~cm} \times 10 \mathrm{~cm}$, but there was also a significant difference between open panels and panels protected by large mesh (Table 3 ).

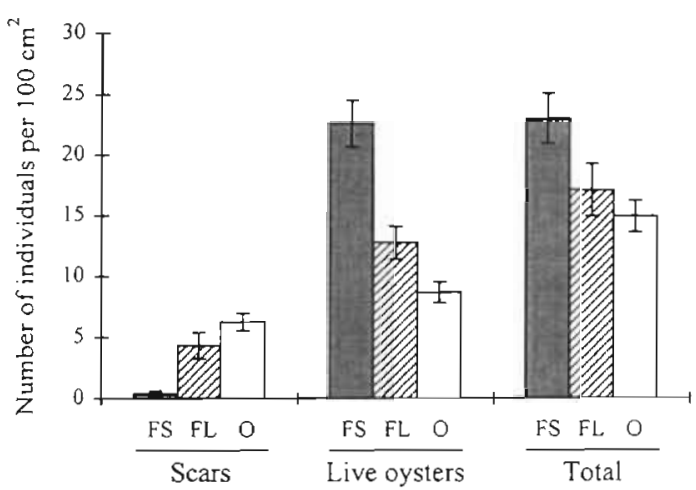

Fig. 3. Mean ( $\pm 1 \mathrm{SE})$ per unit area of numbers of scars, numbers of live oysters and total numbers of scars plus oysters on panels protected by small mesh (FS), large mesh (FL) and open panels $(O)$. There were $n=18$ replicate panels per treatment, after pooling across sticks ( 3 levels) and sizes of panels (3 levels)

\section{DISCUSSION}

\section{Numbers of oysters and mortality}

There was significant mortality of oysters due to predation by fish which did not vary with sizes of panels, indicating that effects were not scale dependent (e.g. Aronson 1994), at least for the range of sizes investigated here. Decreases in numbers of oysters can be attributed to predation by toadfish Tetractenos spp. None of the other potential predators (e.g. bream, snapper, stingray) could have eaten oysters on panels protected with large mesh; toadfish were the only known possible predators that could. The average numbers of oysters on open panels exposed to predation did not differ significantly from the average number on panels accessible only to toadfish (protected with cages of large mesh).

Consideration of mortality suggests, however, that the processes affecting abundances of oysters may be

Table 3. Results of pair-wise 2-sample Kolmogorov-Smirnov tests comparing size-frequency distributions of oysters on panels protected from predation with small mesh and with large mesh and those on open panels. Note: $n_{1}$ and $n_{2}$ indicate sample sizes of the 2 groups being compared. No correction has been made for multiple comparisons

\begin{tabular}{|lcrrc|}
\hline & $\mathrm{D}$ & $\mathrm{n}_{1}$ & $\mathrm{n}_{2}$ & $\mathrm{p}$ \\
\hline $\mathbf{2 0} \mathbf{c m} \times \mathbf{2 0} \mathbf{~ c m}$ & & & & \\
Small vs Open & 0.268 & 470 & 268 & $<0.001$ \\
Small vs Large & 0.151 & 470 & 323 & $<0.001$ \\
Large vs Open & 0.092 & 323 & 268 & $>0.100$ \\
$\mathbf{1 0} \mathbf{c m} \times \mathbf{1 0} \mathbf{~ c m}$ & & & & \\
Small vs Open & 0.291 & 157 & 41 & $<0.010$ \\
Small vs Large & 0.194 & 157 & 89 & $<0.050$ \\
Large vs Open & 0.295 & 89 & 41 & $<0.050$ \\
\hline
\end{tabular}




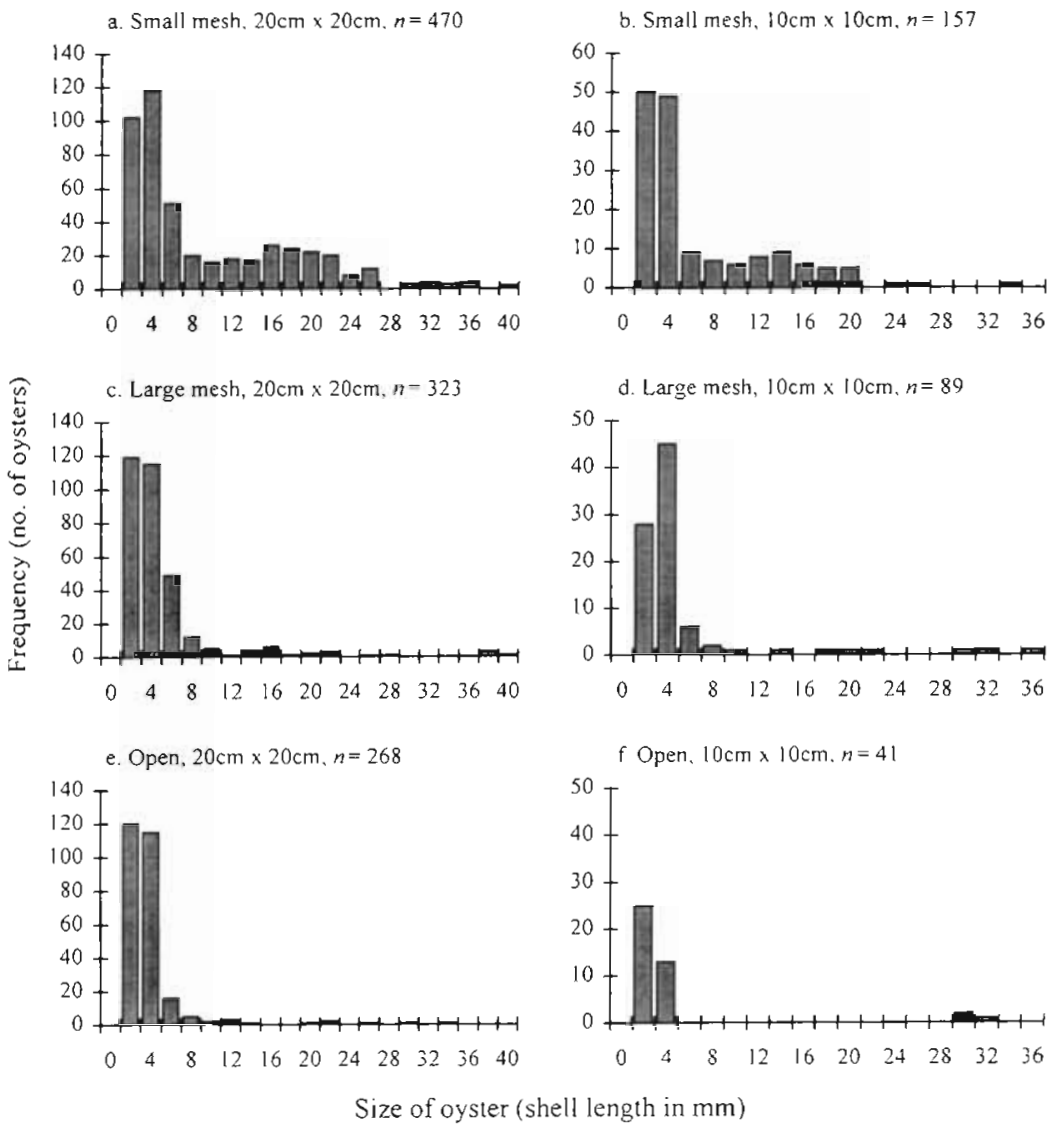

Fig. 4. Size frequency distributions of oysters on panels $(a, b)$ in full cages with small mesh, $(c, d)$ full cages with large mesh or $(e, f)$ on open panels. Note the difference in the scale of the $y$-axis for $20 \mathrm{~cm} \times 20 \mathrm{~cm}$ panels $\left(a_{i}, c_{1}\right)$ versus $10 \mathrm{~cm} \times 10 \mathrm{~cm}$ panels $(b, d, f)$

more complex. Here, there was apparently a gradient in the effect of predation: a decrease in mortality with increases in the degree of protection (i.e. small mesh $\ll$ large mesh $\ll$ open). This might seem puzzling in the light of results obtained for numbers of oysters, where open panels and those protected by large mesh did not differ (i.e. small mesh $>$ large mesh $=$ open). What differs in the measure of mortality (which is equal to the number of scars divided by the number of surviving oysters plus scars) when compared to the simple measure of the number of surviving oysters is the consideration of the number of scars on panels.

In this experiment, oysters provided us with a unique opportunity to measure mortality as distinct from recruitment, due to the fact that oysters leave a scar (their bottom valve) on a surface after being eaten or dying from other causes. By 'recruitment' here, we mean oysters arriving and settling on a surface long enough to have their shells grow to a countable size. Without information on numbers of scars in addition to numbers of live oysters, we would not have found a difference between the open panels and panels protected with large mesh in terms of effects on oysters, yet mortality differed in these 2 treatments.

Previous workers have highlighted the difficulties in interpreting effects of predation using cages (e.g. Choat 1982, Keough \& Downes 1982, Connell 1985, Fairweather 1988, Gosselin \& Qian 1997, Hunt \& Scheibling 1997). In particular, it is generally not possible to separate effects of differential recruitment versus differential post-settlement mortality among treatments (e.g. Choat 1982, Hunt \& Scheibling 1997). For example, cages may enhance recruitment (an experimental artifact), which may be erroneously interpreted as a reduction in post-settlement mortality due to the elimination of predators (Keough \& Downes 1982).

The results obtained for mortality suggest that the intensity of predation on oysters was proportional to the degree of protection of the panels in terms of mesh size. Thus, additional sources of mortality on open panels exist. This suggests alternative models of fish predation in this system: (1) extra sources of mortality for oysters on open panels may be due to predation by other, larger fishes or (2) there is greater intensity of predation by toadfish on open panels than on panels protected by large mesh, perhaps because open panels are more accessible. Further experiments are required to investigate these alternatives.

Nevertheless, the potential productivity of oyster farms is significantly reduced by the loss of oysters to predators on intertidal surfaces. The racks commonly used by oyster farmers are stacked on structures at locations in outer bays where oysters recruit naturally. These racks provide a complex structure of interstices where many fish cannot enter, thus providing some protection from predation (e.g. Nell 1993). The greatest recruitment of oysters, however, occurs on the undersurfaces of the racks, which are open to fish predation. Eventually, farmers generally need to 'thin' the densities of oysters that recruit, giving them room to grow without smothering one another. Although predators can play some immediate role in this 'thinning' process, the overall biomass of oysters produced would be greater if the farmers could catch and maintain as many juveniles as possible in the absence of predation. With the decrease in numbers of juveniles on the order of $40 \%$, farmers would do well to protect their farms from fish predation. 


\section{Effects of predation on sizes of oysters}

Previous studies investigating predation on bivalves of different sizes have focused on the foraging behaviour of predators and energy trade-offs in choosing prey of different sizes (e.g. Elner \& Hughes 1978, Garton 1986. Bisker \& Castagna 1987, Egglestone 1990, Brown \& Haight 1992, Barbeau \& Scheibling 1994. Brown 1997). In addition, studies of oysters as prey have generally found greatest predation on the smallest size classes, or increasing predation with decreasing size of prey, suggesting a size refuge from predation is obtained with growth (Bisker \& Castagna 1987, Egglestone 1990, Brown \& Haight 1992, Brown 1997. Pascual 1997).

In contrast, in this study, the smallest oysters (ca $<8 \mathrm{~mm}$ ) were apparently not eaten by fish. This could have been because fish did not encounter small oysters, did not choose to eat small prey, or because there had not been enough time since settlement of oysters for fish to make any differences in their numbers. This suggests a possible refuge from predation for small oysters.

In addition, fish did not apparently consume oysters larger than $30 \mathrm{~mm}$ (the size of the largest scar), even though live oysters present on panels open to predation measured up to $54 \mathrm{~mm}$. Thus, there also may be a refuge from predation for large in addition to small oysters, with predation being most intense on juveniles of intermediate size. Although no specific tests of this hypothesis have been done, predation on juveniles during a specific post-settlement period could provide an important bottleneck in the life history of oysters.

\section{Effects of predation on succession}

In this study, predation by fish was found to decrease numbers of juvenile oysters, on average, by $40 \%$ (Fig. 2c). It is known that oysters are competitive dominants at outer bays (including Salamander Bay) in the estuaries of New South Wales, due to their rapid growth and ability to overgrow other organisms (Underwood \& Anderson 1994, Anderson 1996). Yet, all previous studies of succession in these assemblages were done in similar circumstances (i.e. on artificial panels attached to oyster leases), but without any protection from predation by fish. So predation cannot be considered to prevent dominance by oysters. It is known that, even where numbers of early recruits vary, similar numbers of oysters per unit area are achieved on surfaces after longer periods, up to 12 mo (Anderson \& Underwood 1994, Anderson 1996). Thus, even with mortality rates of $40 \%$ or greater over the period of juvenile recruitment and growth on hard substrata (as estimated from the present study), oysters eventually dominate available space.

By contrast, removal of gastropod herbivores caused an important shift in the structure of assemblages, from being dominated by oysters, to being dominated by barnacles and algae (Anderson \& Underwood 1997). Grazers, by removing algae, indirectly enhance recruitment of oysters (Anderson 1999). Even though predation by fish on oysters has not been explicitly measured for longer periods than in this study, it is clear from long-term studies of open panels that natural levels of predation do not prevent oysters from eventually dominating (Anderson 1996). Therefore, grazing by gastropods may be more important in shaping assemblages and succession in these systems than is predation by fish.

These results differ importantly from results of intertidal studies where predation plays a key role in regulating distributions of some mussels (e.g. Paine 1974, Menge \& Sutherland 1976), or dominance by mussels may be prevented by other mechanisms such as the lack of appropriate sites for settlement (Petraitis 1990) or physical disturbance (Dayton 1971).

Predation by fish on oysters, although greatly reducing numbers of juvenile recruits, is not extensive enough to counteract the consistent recruitment of oysters and indirect positive effects of grazers on recruitment of oysters. Fish predation may, however, negatively affect abundances of grazers (Underwood \& Barrett 1990, Connell \& Anderson 1999). Also, predation on juvenile oysters may create temporary patches of open space for other organisms (such as ephemeral algae, bryozoans or spirorbids, Connell \& Anderson 1999). Further study, including manipulation of grazers and fish in an examination of simultaneous effects, is required over longer periods and at various sites to determine the ultimate role of predation, if any, on succession of oysters and other organisms in these assemblages.

Acknowledgements. This study was supported by a University of Sydney U2000 post-doctoral fellowship to M.J.A. and funds from the Centre for Research on Ecological Impacts of Coastal Cities. The work benefited from discussions with A. $\boldsymbol{J}$. Underwood, J. Nell, M. Beck, J. Leis and V. Kennedy. We gratefully acknowledge field assistance from $T$. Glasby and logistic support from G. Housefield, T. Davies and S. Heislers. M. Haddon helped build cages and B. Gillanders let us use her net for seining.

\section{LITERATURE CITED}

Anderson MJ (1996) Tests of ecological hypotheses in intertidal estuarine assemblages. PhD thesis, University of Sydney, NSW

Anderson MJ (1998) Effects of patch size on colonisation in 
estuaries: revisiting the species-area relationship. Oecologia 118:87-98

Anderson MJ (1999) Distinguishing direct from indirect effects of grazers in intertidal estuarine assemblages. J Exp Mar Biol Ecol 234:199-218

Anderson MJ, Underwood AJ (1994) Effects of substratum on the recruitment and development of an intertidal estuarine fouling assemblage. J Exp Mar Biol Ecol 184:217-236

Anderson MJ, Underwood A.J (1997) Effects of gastropod grazers on recruitment and succession of an estuarine assemblage: a multivariate and univariate approach. Oecologia 109:442-453

Aronson RB (1994) Scale-independent biological processes in the marine environment. Oceanogr Mar Biol Annu Rev $32: 435-460$

Ayling AM (1981) The role of biological disturbance in temperate subtidal encrusting communities. Ecology 62: $830-847$

Barbeau MA, Scheibling RE (1994) Behavioral mechanisms of prey size selection by sea stars (Asterias vulganis Verrill) and crabs (Cancer irroratus Say) preying on juvenile sea scallops (Placopecten magellanicus (Gmelin)). J Exp Mar Biol Ecol 182:27-47

Barkai A, Branch GM (1988) The influence of predation and substratal complexity on recruitment to settlement plates: a test of the theory of alternative states. J Exp Mar Biol Ecol 124:215-237

Bisker R, Castagna M (1987) Predation on single spat oysters Crassostrea virginica (Gmelin) by blue crabs Callinectes sapidus Rathbun and mud crabs Panopeus herbstii MilneEdwards. J Shellfish Res 6(1):37-40

Brown KM (1997) Size-specific aspects of the foraging ecology of the southern oyster drill Stramonita haemastoma (Kool 1987). J Exp Mar Biol Ecol 214:249-262

Brown KM, Haight ES (1992) The foraging ecology of the Gulf of Mexico stone crab Menippe adina (Williams et Felder) J Exp Mar Biol Ecol 160:67-80

Choat JH (1982) Fish feeding and the structure of benthic communities in temperate waters. Annu Rev Ecol Syst 13 $423-229$

Connell JH (1961) Effects of competition, predation by Thais lapillus, and other factors on natural populations of the barnacle Balanus balanoides. Ecol Monogr 31:61-104

Connell JH (1985) The consequences of variation in initial settlement vs. post-settlement mortality in rocky intertidal communities. J Exp Mar Biol Ecol 93:11-45

Connell SD (1997) Exclusion of predatory fish on a coral reef: the anticipation, pre-emption and evaluation of some caging artifacts. J Exp Mar Biol Ecol 213:181-198

Connell SD, Anderson MJ (1999) Predation by fish on assemblages of intertidal epibiota: effects of predator size and patch size. J Exp Mar Biol Ecol 241:15-29

Creese RG (1982) Distribution and abundance of the Acmaeid limpet, Patelloida latistrigata, and its interaction with barnacles. Oecologia 52:85-96

Dayton PK (1971) Competition, disturbance and community organization: the provision and subsequent utilization of space in a rocky intertidal community. Ecol Monogr 41 : $351-389$

Dungan ML (1987) Indirect mutualism: complementary effects of grazing and predation in a rocky intertidal community. In: Kerfoot WC, Sih A (eds) Predation: direct and indirect impacts on aquatic communities. University Press of New England, Hanover, NH, p 188-200

Egglestone DB (1990) Foraging behavior of the blue crab, Callinectes sapidus, on juvenile oysters, Crassostrea virginica: effects of prey density and size. Bull Mar Sci 46:62-82
Elner RW, Hughes RN (1978) Energy maximization in the diet of the shore crab, Carcinus maenas. J Anim Ecol 47 . $103-116$

Elner RW, Lavoie RE (1983) Predation on American oysters (Crassostrea virginica (Gmelin)) by American lobsters (Homarus americanus Milne-Edwards), rock crabs (Cancer irroratus Say), and mud crabs (Neopanope sayi (Smith)). J Shellfish Res 3(2):129-1.34

Fairweather PG (1988) Consequences of supply-side ecology: manipulating the recruitment of intertidal barnacles affects the intensity of predation upon them. Biol Bull $175: 349-354$

Garton DW (1986) Effect of prey size on the energy budget of a predatory gastropod, Thais haemastoma canaliculata (Gray). J Exp Mar Biol Ecol 98:21-33

Gosselin LA, Qian PY (1997) Juvenile mortality in benthic marine invertebrates. Mar Ecol Prog Ser 146:265-282

Harris LG, Irons KP (1982) Substrate angle and predation as determinants in fouling community succession. In: Cairns $J$ (ed) Artificial substrates. Ann Arbor Science Publishers, Inc, Ann Arbor, MI, p 131-174

Hunt HL, Scheibling RE (1997) Role of early post-settlement mortality in recruitment of benthic marine invertebrates. Mar Ecol Prog Ser 155:269-301

Jernakoff P, Fairweather PG (1985) An experimental analysis of interactions among several intertidal organisms. $J$ Exp Mar Biol Ecol 94:71-88

Karlson R (1978) Predation and space utilization patterns in a marine epifaunal community. J Exp Mar Biol Ecol 31 $225-239$

Kennelly SJ (1991) Caging experiments to examine the effects of fishes on understorey species in a sublittoral kelp community. J Exp Mar Biol Ecol 147:207-230

Keough MJ, Downes BJ (1982) Recruitment of marine invertebrates: the role of active larval choices and early mortality. Oecologia 54:348-352

Korringa P (1976) Farming the cupped oysters of the genus Crassostrea. Elsevier Scientific, Amsterdam

Krantz GE, Chamberlain JV (1978) Blue crab predation on cultchless oyster spat. Proc Natl Shellfish Assoc 68:38-41

Littlewood DTJ (1989) Predation on cultivated Crassostrea rhizophorae (Guilding) by the gastropod Cymatium pileare (Linnaeus). J Mollusc Stud 55:125-127

Littlewood DTJ, Marsbe LA (1990) Predation on cultivated oysters, Crassostrea rhizophorae (Guilding), by polyclad turbellarian flatworm, Stylochus (Stylochus) frontalis Verrill. Aquaculture 88:145-150

McDermott J (1964) Food habits of the toadfish, Opsanus tau (L), in New Jersey waters. Proc PA Acad Sci 38:64-71

Menge BA, Sutherland JP (1976) Species diversity gradients: synthesis of the roles of predation, competition, and temporal heterogeneity. Am Nat 110:351-369

Menge BA, Lubchenco J, Ashkenas LR, Ramsey F (1986) Experimental separation of effects of consumers on sessile prey in the low zone of a rocky shore in the bay of Panama: direct and indirect consequences of food web complexity. J Exp Mar Biol Ecol 100:225-269

Nell JA (1993) Farming the Sydney Rock oyster (Saccostrea commercialis) in Australia. Rev Fish Sci 1:2:97-120

New South Wales Fisheries (1996) Aquaculture Branch Database, Sydney, NSW

Ogle JT, Beaugez K (1988) Oyster hatcheries on the Gulf coast: history, current technology and future trends. J Shellfish Res 7(3):505-509

Paine RT (1974) Intertidal community structure. Experimental studies on the relationship between a dominant competitor and its principal predator. Oecologia 39:1-24 
Pascual MS (1997) Carriage of dwarf males by adult female puelche oysters: the role of chitons. J Exp Mar Biol Ecol 212:173-185

Petraitis PS (1990) Direct and indirect effects of predation, herbivory and surface rugosity on mussel recruitment. Oecologia 83:405-413

Roegner GC, Mann R (1990) Settlement patterns of Crassostrea virginica (Gmelin, 1791) larvae in relation to tidal zonation. J Shellfish Res 9(2):341-346

Russ GR (1980) Effects of predation by fishes, competition, and structural complexity of the substratum on the establishment of a marine epifaunal community. J Exp Mar Biol Ecol 42:55-69

Schmidt GH, Warner GF (1984) Effects of caging on the development of a sessile epifaunal community. Mar Ecol Prog Ser 15:251-263

Editorial responsibility: Antony Underwood (Contributing Editor), Sydney, Australia
Sokal RR, Rohlf FJ (1981) Biometry, 2nd edn. WH Freeman and $\mathrm{Co}$, New York

Tuckwell J, Nol E (1997) Intra- and inter-specific interactions of foraging American oystercatchers on an oyster bed. Can J Zool 75:182-187

Underwood AJ, Anderson MJ (1994) Seasonal and temporal aspects of recruitment and succession in an intertidal estuarine fouling assemblage. J Mar Biol Assoc UK 74:563-584

Underwood AJ, Barrett G (1990) Experiments on the influence of oysters on the distribution, abundance and sizes of the gastropod Bembicium auratum in a mangrove swamp in New South Wales, Australia. J Exp Mar Biol Ecol 137:25-45

Wisely B, Holliday JE, Reid BL (1979) Experimental deepwater culture of the Sydney Rock oyster (Crassostrea commercialis = Saccostrea cucullata). I. Growth of vertical clumps of oysters ('ren'). Aquaculture 16:127-140

Submitted: August 4, 1998, Accepted: May 7, 1999

Proofs received from author(s): September 24, 1999 